\title{
Front Matter: Volume 9076
}

, "Front Matter: Volume 9076," Proc. SPIE 9076, Airborne Intelligence, Surveillance, Reconnaissance (ISR) Systems and Applications XI, 907601 (17 June 2014); doi: 10.1117/12.2072100

SPIE. Event: SPIE Defense + Security, 2014, Baltimore, MD, United States 


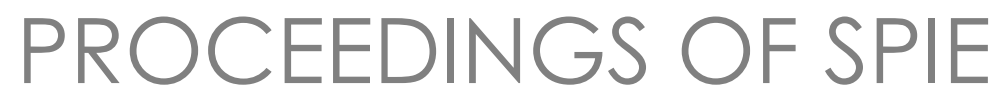

\title{
Airborne Intelligence, Surveillance, Reconnaissance (ISR) Systems and Applications XI
}

\author{
Daniel J. Henry \\ Davis A. Lange \\ Dale Linne von Berg \\ S. Danny Rajan \\ Thomas J. Walls \\ Darrell L. Young \\ Editors
}

7-8 May 2014

Baltimore, Maryland, United States

Sponsored and Published by

SPIE 
The papers included in this volume were part of the technical conference cited on the cover and title page. Papers were selected and subject to review by the editors and conference program committee. Some conference presentations may not be available for publication. The papers published in these proceedings reflect the work and thoughts of the authors and are published herein as submitted. The publisher is not responsible for the validity of the information or for any outcomes resulting from reliance thereon.

Please use the following format to cite material from this book:

Author(s), "Title of Paper," in Airborne Intelligence, Surveillance, Reconnaissance (ISR) Systems and Applications XI, edited by Daniel J. Henry, Davis A. Lange, Dale Linne von Berg, S. Danny Rajan, Thomas J. Walls, Darrell L. Young, Proceedings of SPIE Vol. 9076 (SPIE, Bellingham, WA, 2014) Article CID Number.

ISSN: 0277-786X

ISBN: 9781628410136

Published by

SPIE

P.O. Box 10, Bellingham, Washington 98227-0010 USA

Telephone +1 3606763290 (Pacific Time) · Fax +1 3606471445

SPIE.org

Copyright (C) 2014, Society of Photo-Optical Instrumentation Engineers.

Copying of material in this book for internal or personal use, or for the internal or personal use of specific clients, beyond the fair use provisions granted by the U.S. Copyright Law is authorized by SPIE subject to payment of copying fees. The Transactional Reporting Service base fee for this volume is $\$ 18.00$ per article (or portion thereof), which should be paid directly to the Copyright Clearance Center (CCC), 222 Rosewood Drive, Danvers, MA 01923. Payment may also be made electronically through CCC Online at copyright.com. Other copying for republication, resale, advertising or promotion, or any form of systematic or multiple reproduction of any material in this book is prohibited except with permission in writing from the publisher. The CCC fee code is 0277-786X/14/\$18.00.

Printed in the United States of America.

Publication of record for individual papers is online in the SPIE Digital Library.

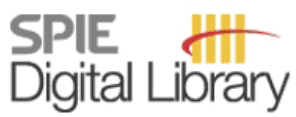

SPIEDigitalLibrary.org

Paper Numbering: Proceedings of SPIE follow an e-First publication model, with papers published first online and then in print and on CD-ROM. Papers are published as they are submitted and meet publication criteria. A unique, consistent, permanent citation identifier (CID) number is assigned to each article at the time of the first publication. Utilization of CIDs allows articles to be fully citable as soon as they are published online, and connects the same identifier to all online, print, and electronic versions of the publication. SPIE uses a six-digit CID article numbering system in which:

- The first four digits correspond to the SPIE volume number.

- The last two digits indicate publication order within the volume using a Base 36 numbering

system employing both numerals and letters. These two-number sets start with 00, 01, 02, 03, 04, $05,06,07,08,09,0 A, 0 B \ldots$. 0Z, followed by 10-1Z, 20-2Z, etc.

The CID Number appears on each page of the manuscript. The complete citation is used on the first page, and an abbreviated version on subsequent pages. Numbers in the index correspond to the last two digits of the six-digit CID Number. 


\title{
Contents
}

\author{
vii Conference Committee \\ ix Introduction
}

\section{SESSION 1 ISR IMAGE PROCESSING}

907602 High-performance electronic image stabilisation for shift and rotation correction [9076-2] S. C. J. Parker, RFEL Ltd. (United Kingdom); D. L. Hickman, Tektonex Ltd. (United Kingdom); F. Wu, RFEL Ltd. (United Kingdom)

907603 Identification of spatially corresponding imagery using content-based image retrieval in the context of UAS video exploitation [9076-3]

S. Brüstle, D. Manger, K. Mück, N. Heinze, Fraunhofer-Institut für Optronik, Systemtechnik und Bildauswertung (Germany)

907604 Meta-image navigation augmenters for GPS denied mountain navigation of small UAS [9076-4]

T. Wang, K. Çelik, A. K. Somani, lowa State Univ. (United States)

907605 Parallax visualization of full motion video using the Pursuer GUI [9076-5]

C. A. Mayhew, M. B. Forgues, Vision III Imaging, Inc. (United States)

\section{SESSION 2 ISR VIDEO PROCESSING}

907606 Effect of video decoder errors on video interpretability [9076-6]

D. L. Young, Raytheon Intelligence \& Information Systems (United States)

907607 Multi-frame image processing with panning cameras and moving subjects [9076-7] A. Paolini, J. Humphrey, P. Curt, E. Kelmelis, EM Photonics, Inc. (United States)

907608 Marine object detection in UAV full-motion video [9076-8]

S. Parameswaran, C. Lane, B. Bagnall, H. Buck, Space and Naval Warfare Systems Ctr. Pacific (United States)

907609 A comparison of moving object detection methods for real-time moving object detection [9076-9]

A. Roshan, Y. Zhang, Univ. of New Brunswick (Canada)

$90760 \mathrm{~A}$ Improved frame differencing based moving object detection using feet-step sound [9076-10]

A. Roshan, Y. Zhang, Univ. of New Brunswick (Canada) 
9076 OC Near-space airships against terrorist activities [9076-12]

C. Kesenek, Turkish Air War College (Turkey)

9076 OD IITET and shadow TT: an innovative approach to training at the point of need [9076-13] A. Gross, F. Lopez, J. Dirkse, D. Anderson, Trideum Corp. (United States); S. Berglie, KINEX (United States); C. May, S. Harkrider, U.S. Army Night Vision \& Electronic Sensors Directorate (United States)

\section{SESSION $4 \quad$ ISR OPTICS AND GIMBALS}

9076 OE Optical line-of-sight steering using gimbaled mirrors [9076-14]

S. Satyarthi, IJK Controls LLC (United States)

9076 OF Line-of-sight kinematics and corrections for fast-steering mirrors used in precision pointing and tracking systems [9076-15]

J. M. Hilkert, Univ. of Texas at Dallas (United States); G. Kanga, K. Kinnear, Lockheed Martin Missiles and Fire Control (United States)

9076 OG Application of phase matching autofocus in airborne long-range oblique photography camera [9076-16]

V. Petrushevsky, A. Guberman, Elbit Systems ElectroOptics Ltd. (Israel)

\section{SESSION $5 \quad$ ISR SENSORS I}

$9076 \mathrm{OH} \quad$ Automated multi-INT fusion for tactical reconnaissance [9076-17]

T. J. Walls, A. J. Boudreau, M. L. Wilson, U.S. Naval Research Lab. (United States); J. R. Haws,

T. Johnson, B. Petersen, Space Dynamics Lab. (United States)

9076 Ol NV-CMOS HD camera for day/night imaging [9076-18]

T. Vogelsong, J. Tower, T. Sudol, T. Senko, D. Chodelka, SRI International Sarnoff (United States)

\section{SESSION $6 \quad$ ISR SENSORS II}

9076 OK Polarimetric sensor systems for airborne ISR [9076-21]

D. Chenault, J. Foster, J. Pezzaniti, J. Harchanko, T. Aycock, Polaris Sensor Technologies, Inc. (United States); A. Clark, Intuitive Research and Technology Corp. (United States)

9076 OL Real-time aerial multispectral imaging solutions using dichroic filter arrays [9076-22] E. V. Chandler, D. E. Fish, Pixelteq, Inc. (United States)

9076 OM 9-band SWIR multispectral sensor providing full-motion video [9076-23]

M. R. Kutteruf, M. K. Yetzbacher, U.S. Naval Research Lab. (United States); M. J. Deprenger, K. M. Novak, C. A. Miller, Tekla Research, Inc. (United States); A. Kanaev, U.S. Naval Research Lab. (United States) 
POSTER SESSION

9076 ON Robust real-time horizon detection in full-motion video [9076-25]

G. B. Young, La Jolla High School (United States); B. Bagnall, C. Lane, S. Parameswaran, Space and Naval Warfare Systems Ctr. Pacific (United States)

907600 Fusion of thermal infrared and visible spectrum for robust pedestrian tracking [9076-26]

M. A. Akhloufi, C. Porcher, Ctr. of Industrial Robotics and Vision (Canada); A. Bendada, Univ. Laval (Canada)

Author Index 
Proc. of SPIE Vol. $9076907601-6$

Downloaded From: https://www.spiedigitallibrary.org/conference-proceedings-of-spie on 26 Apr 2023 Terms of Use: https://www.spiedigitallibrary.org/terms-of-use 


\title{
Conference Committee
}

\author{
Symposium Chair
}

David A. Whelan, Boeing Defense, Space, and Security (United States)

Symposium Co-chair

Nils R. Sandell Jr., Strategic Technology Office, DARPA (United States)

Conference Chair

Daniel J. Henry, Rockwell Collins, Inc. (United States)

Conference Co-chairs

Davis A. Lange, UTC Aerospace Systems (United States)

Dale Linne von Berg, U.S. Naval Research Laboratory (United States)

S. Danny Rajan, Exelis Inc. (United States)

Thomas J. Walls, U.S. Naval Research Laboratory (United States)

Darrell L. Young, Raytheon Intelligence \& Information Systems

(United States)

Session Chairs

1 ISR Image Processing

Gregory J. Gosian, Exelis Inc. (United States)

2 ISR Video Processing

Darrell L. Young, Raytheon Intelligence \& Information Systems (United States)

3 ISR Strategies and Training

Daniel J. Henry, Rockwell Collins, Inc. (United States)

4 ISR Optics and Gimbals

Davis A. Lange, UTC Aerospace Systems (United States)

5 ISR Sensors I

Thomas J. Walls, U.S. Naval Research Laboratory (United States)

6 ISR Sensors II

Dale Linne von Berg, U.S. Naval Research Laboratory (United States) 
Proc. of SPIE Vol. $9076907601-8$

Downloaded From: https://www.spiedigitallibrary.org/conference-proceedings-of-spie on 26 Apr 2023 Terms of Use: https://www.spiedigitallibrary.org/terms-of-use 


\section{Introduction}

This year's conference brought a wide range of papers related to ISR Systems and Applications. The conference was broken into multiple sessions, which addressed several different parts of the ISR TCPED image chain (Tasking, Capture, Processing, Exploitation, and Dissemination):

- $\quad$ Strategies and Training

- Optics and Gimbals

- $\quad$ Sensors

- $\quad$ Image Processing

- Video Processing

We would like to thank all the authors for their efforts to make our conference such a success. Their efforts to write and present their papers are greatly appreciated. Their innovations in this exciting field make our conference better each year, and we look forward to the 2015 conference to see what additional advances have been made in these areas, as well as the introduction of new technologies that have been developed.

See you at DSS 2015 !

Daniel J. Henry

Davis A. Lange

Dale Linne von Berg

S. Danny Rajan

Thomas J. Walls

Darrell L. Young 
Proc. of SPIE Vol. $9076907601-10$

Downloaded From: https://www.spiedigitallibrary.org/conference-proceedings-of-spie on 26 Apr 2023 Terms of Use: https://www.spiedigitallibrary.org/terms-of-use 